\title{
Effect of dietary mineral phosphorus and phytate on in situ ruminal phytate disappearance from different concentrates in dairy cows
}

\author{
E. Haese, ${ }^{*}$ J. Möhring, † H. Steingass, ${ }^{*}$ M. Schollenberger, ${ }^{*}$ and M. Rodehutscord ${ }^{* 1}$ \\ *Institut für Nutztierwissenschaften, Universität Hohenheim, 70599 Stuttgart, Germany \\ †Institut für Kulturpflanzenwissenschaften, Fachgebiet Biostatistik, Universität Hohenheim, 70599 Stuttgart, Germany
}

\begin{abstract}
The first objective of this study was to determine the influence of dietary composition on the in situ disappearance of phytate $\left(\mathrm{InsP}_{6}\right)$ from wheat, corn, soybean meal, and rapeseed meal [solvent-extracted, without (RSM) or with (hRSM) heat treatment] in the rumen of dairy cows. The second objective was to assess the primary degradation products of $\mathrm{InsP}_{6}$ in the rumen. Three diets differing in phosphorus and $\operatorname{InsP}_{6}$ concentration (basal diet $=0.38 \% \mathrm{P}$ in dry matter; high-P diet $=0.56 \% \mathrm{P}$; high-InsP $\mathrm{P}_{6}$ diet $=0.39 \% \mathrm{P}$ ) were fed to 3 ruminally fistulated lactating Jersey cows in a $3 \times 3$ Latin square. Ground concentrates (sieve size $=2 \mathrm{~mm}$ ) were incubated in polyester bags in the rumen for $2,4,8,16$, and $24 \mathrm{~h}$. The bag residues were analyzed for $\mathrm{P}, \mathrm{InsP}_{6}$, isomers of lower inositol phosphates $\left(\mathrm{InsP}_{5}, \mathrm{InsP}_{4}, \mathrm{InsP}_{3}\right)$, and crude protein. The $\mathrm{InsP}_{6}$ disappeared more rapidly from cereal grains than from oilseed meals; however, after $24 \mathrm{~h}$ of incubation $\geq 95 \%$ InsP $_{6}$ had disappeared from all concentrates except hRSM (57\%; diet average). Feeding the high$\mathrm{InsP}_{6}$ diet increased $\mathrm{InsP}_{6}$ disappearance for oilseed meals, but not for corn and wheat. The predominant $\mathrm{InsP}_{5}$ isomer in all bag residues was $\operatorname{Ins}(1,2,4,5,6) \mathrm{P}_{5}$ followed by $\operatorname{Ins}(1,2,3,4,5) \mathrm{P}_{5}$ and $\operatorname{Ins}(1,2,3,4,6) \mathrm{P}_{5}$. A further $\operatorname{InsP}_{5}$ isomer $\left[\operatorname{Ins}(1,3,4,5,6) \mathrm{P}_{5}\right]$ was detected in both rapeseed meal bag residues. Feeding the high$\mathrm{InsP}_{6}$ diet led to lower concentrations of $\operatorname{Ins}(1,2,4,5,6)$ $\mathrm{P}_{5}$ and $\operatorname{Ins}(1,2,3,4,5) \mathrm{P}_{5}$, whereas an interaction between diet, concentrate, and time occurred for $\operatorname{Ins}(1,2,3,4,6)$ $\mathrm{P}_{5}$ and Ins $(1,3,4,5,6) \mathrm{P}_{5}$. The results confirm the high potential of rumen microorganisms to hydrolyze $\mathrm{InsP}_{6}$; however, increasing the amount of $\mathrm{InsP}_{6}$ in the diet can further enhance $\operatorname{InsP}_{6}$ hydrolysis, which may be relevant when concentrates with slowly degradable $\mathrm{InsP}_{6}$, such as RSM or heat-treated concentrates, are
\end{abstract}

Received May 16, 2016.

Accepted January 24, 2017.

${ }^{1}$ Corresponding author: inst450@uni-hohenheim.de fed to dairy cows. Based on the concentrations of $\operatorname{InsP}_{5}$ isomers, 3 and 6 phytases appear to play a major role in the rumen. Conversely, intrinsic plant phytase activity appears to be less relevant as the percentage of its primary hydrolysis product, Ins $(1,2,3,4,5) \mathrm{P}_{5}$, changed only slightly upon using wheat known for high intrinsic phytase activity instead of the other concentrates. Additional information regarding the factors influencing the extent of ruminal $\mathrm{InsP}_{6}$ disappearance will require further studies to determine the phytase activity of rumen microorganisms and the characteristics of their respective phytases.

Key words: phytate, rumen, degradation, inositol pentakisphosphates

\section{INTRODUCTION}

Phytate, defined as any salt of phytic acid [myoinositol 1,2,3,4,5,6-hexakis (dihydrogen phosphate); InsP $_{6}$ ], is the major storage form of $\mathrm{P}$ in plant seeds. The availability of $\mathrm{P}$ bound in $\mathrm{InsP}_{6}$ depends on $\mathrm{InsP}_{6}$ hydrolytic cleavage, which is catalyzed by phytases. Ruminants effectively hydrolyze $\mathrm{InsP}_{6}$ owing to the phytase activity of ruminal microorganisms (Raun et al., 1956; Yanke et al., 1998). Digestibility studies with dairy cows measuring fecal $\operatorname{InsP}_{6}$ excretion confirm high $\mathrm{InsP}_{6}$ hydrolysis ranging from 93 to $99 \%$ (Clark et al., 1986; Morse et al., 1992; Ray et al., 2013); however, several factors influence the extent of $\mathrm{InsP}_{6}$ hydrolysis. Differences in $\mathrm{InsP}_{6}$ hydrolysis between feedstuffs (Konishi et al., 1999; Park et al., 1999; Blaabjerg et al., 2010; Brask-Pedersen et al., 2011; Haese et al., 2016) may be due to different localization sites and storage forms in the seeds (Haese et al., 2016). Feedstuff processing methods, such as heat (Konishi et al., 1999; Blaabjerg et al., 2007) or formaldehyde treatment (Park et al., 1999; Martín-Tereso et al., 2009), further affect $\mathrm{InsP}_{6}$ hydrolysis, as can diet composition. Increased dietary $\mathrm{InsP}_{6}$ concentration led to higher ruminal (Ray et al., 2013) and total-tract (Haese et al., 2014) $\operatorname{InsP}_{6}$ disappearance, whereas mineral $\mathrm{P}$ addition decreased total-tract $\mathrm{InsP}_{6}$ disappearance in vivo (Haese et al., 
2014). Similar effects occurred in vitro upon inorganic $\mathrm{P}$ addition to the buffer in the system (Godoy and Meschy, 2001; Haese et al., 2016). However, it is difficult to unambiguously determine factors influencing $\mathrm{InsP}_{6}$ hydrolysis through multistudy comparison, as studies may differ in several associated characteristics, such as DMI, diet ingredients, or sampling or analytical methods. Furthermore, factors observed in vitro might not necessarily apply in vivo.

Phosphorus is an essential mineral for health maintenance, milk production, and reproduction, although it may contribute to environmental pollution when excreted. To ensure an optimal P supply while avoiding unnecessary excretion, the ruminal availability of $\operatorname{InsP}_{6}$ from different feedstuffs and the factors influencing its hydrolysis are of highest interest.

Therefore, we first aimed to determine the effects of different inorganic $\mathrm{P}$ or $\mathrm{InsP}_{6}$ concentrations in the diet of dairy cows on the in situ disappearance of $\operatorname{InsP}_{6}$. For incubation, we used 5 concentrates commonly used in ruminant nutrition: wheat, corn, soybean meal (SBM), and 2 rapeseed meals (RSM) because of their differing $\mathrm{InsP}_{6}$ concentrations, localizations, and storage forms. We hypothesized that these differences would

Table 1. Ingredients and chemical composition of the experimental diets fed to fistulated Jersey cows

\begin{tabular}{|c|c|c|c|}
\hline \multirow[b]{2}{*}{ Item } & \multicolumn{3}{|c|}{$\operatorname{Diet}^{1}$} \\
\hline & Basal & $\mathrm{Pi}$ & InsP \\
\hline \multicolumn{4}{|l|}{$\begin{array}{l}\text { Ingredient } \\
(\%, \text { on DM basis, unless noted })\end{array}$} \\
\hline Corn silage & 24.2 & 23.9 & 23.4 \\
\hline Grass silage & 32.2 & 31.9 & 31.2 \\
\hline Meadow hay & 16.1 & 16.0 & 15.6 \\
\hline Corn gluten & 6.4 & 6.4 & - \\
\hline Corn starch & 4.0 & 4.0 & 1.6 \\
\hline Corn grain & - & - & 11.7 \\
\hline Dried sugar beet pulp & 16.1 & 16.0 & - \\
\hline Rapeseed meal, solvent extracted & - & - & 15.6 \\
\hline Monosodium phosphate & - & 0.6 & - \\
\hline Monocalcium phosphate & - & 0.8 & - \\
\hline $\mathrm{NaCl}$ & 0.4 & 0.1 & 0.4 \\
\hline $\mathrm{CaCO}_{3}$ & 0.4 & - & 0.5 \\
\hline Urea & 0.2 & 0.3 & - \\
\hline $\mathrm{DM}(\mathrm{g} / \mathrm{kg})$ & 394 & 398 & 397 \\
\hline \multicolumn{4}{|l|}{ Chemical composition ( $\mathrm{g} / \mathrm{kg}$ of $\mathrm{DM})$} \\
\hline $\mathrm{OM}$ & 926 & 921 & 928 \\
\hline $\mathrm{CP}$ & 113 & 118 & 120 \\
\hline Total P & 3.82 & 5.59 & 3.94 \\
\hline $\mathrm{InsP}_{6}$ & 0.44 & 0.48 & 3.45 \\
\hline $\mathrm{InsP}_{6}-\mathrm{P}^{2}$ & 0.13 & 0.13 & 0.97 \\
\hline
\end{tabular}

${ }^{1}$ Basal $=\mathrm{P}$ content of $3.82 \mathrm{~g} / \mathrm{kg}$ of $\mathrm{DM} ; \mathrm{Pi}=$ inorganic $\mathrm{P}$ diet with monosodium and monocalcium phosphate $(5.59 \mathrm{~g} / \mathrm{kg}$ of DM); InsP = exclusively organic $\mathrm{P}$ diet $(3.94 \mathrm{~g}$ of $\mathrm{P} / \mathrm{kg}$ of $\mathrm{DM})$, with rapeseed meal as the main source of phytate $\left(\operatorname{InsP}_{6}\right)$.

${ }^{2}$ Phosphorus bound in $\mathrm{InsP}_{6}$. cause the diet composition to differentially influence $\mathrm{InsP}_{6}$ disappearance from the incubated concentrates. Detailed information on this process may be useful to develop specific recommendations for formulating diets to optimize ruminal $\operatorname{InsP}_{6}$ hydrolysis. Because $\operatorname{InsP}_{6}$ accumulates together with storage proteins in protein storage vacuoles (PSV; Gillespie et al., 2005) and can bind proteins in several feedstuffs (Selle et al., 2012), we also analyzed $\mathrm{CP}$ concentrations of the bag residues. As strong interactions between protein and $\mathrm{InsP}_{6}$ occur in soybean (Tombs, 1967; O'Dell and de Boland, 1976) and rapeseed proteins (Gillberg and Törnell, 1976), we examined whether ruminal $\mathrm{CP}$ disappearance was associated with $\mathrm{InsP}_{6}$ disappearance from concentrates.

Our second aim was to learn about the phytases involved in ruminal $\mathrm{InsP}_{6}$ degradation by determining the main degradation products. Phytases are divided into 3- (EC 3.1.3.8), 6- (EC 3.1.3.26), and 5-phytases (EC 3.1.3.72; Greiner and Konietzny, 2006), referring to the position of the carbon in the myo-inositol ring of $\mathrm{InsP}_{6}$ at which dephosphorylation is initiated. Thus, the spectrum of Ins $_{5}$ isomers in the bag residues provides information about active phytases in the rumen. We analyzed these spectra at all incubation times to determine possible differences in the involved phytases between concentrates and diets.

\section{MATERIALS AND METHODS}

\section{Animals and Diets}

We used 3 mid-lactation rumen-fistulated Jersey cows for this study with an average DMI of $15 \mathrm{~kg} / \mathrm{d}$. The cows were housed in a freestall barn with cubicles covered with rubber mats and chopped straw and milked twice daily at 0500 and $1600 \mathrm{~h}$. The experiment was designed as a $3 \times 3$ Latin square with 3 cows and 3 diets tested in 3 periods. The $\mathrm{P}$ content of the basal diet was $3.82 \mathrm{~g} / \mathrm{kg}$ of DM (Table 1), which was in accordance with the recommendations of the Gesellschaft für Ernährungsphysiologie (GfE, 2001). Two further diets, differing in $\mathrm{P}$ or phytate content, were also prepared. Inorganic $\mathrm{P}$ was added as monosodium and monocalcium phosphate to the basal diet $(\mathbf{P i} ; 5.59$ $\mathrm{g}$ of $\mathrm{P} / \mathrm{kg}$ of $\mathrm{DM})$. The third diet $(3.94 \mathrm{~g}$ of $\mathrm{P} / \mathrm{kg}$ of $\mathrm{DM}$ ) contained $\mathrm{P}$ exclusively of organic origin, with RSM provided as the main source of $\operatorname{InsP}_{6}$ (InsP). To achieve similar $\mathrm{CP}$ and energy concentrations between the 3 diets, corn gluten, corn starch, and dried sugar beet pulp in diet InsP were substituted with corn grain and RSM.

The diets were prepared every morning as a TMR and filled into weighing troughs (Westfalia Surge, 
Bönen, Germany) with Calan gates (American Calan, Northwood, NH) at $0800 \mathrm{~h}$. Cows received individual amounts of TMR to ensure adequate energy and protein supply according to their respective milk yield. Water was provided for ad libitum consumption day and night.

Before starting the ruminal incubation, cows were adapted to their respective diets for $14 \mathrm{~d}$. Samples of the freshly prepared TMR were taken twice during the adaption period and every morning during the incubation period and immediately frozen. At the end of each incubation period, the TMR samples were thawed, dried $\left(65^{\circ} \mathrm{C}\right.$ for $\left.48 \mathrm{~h}\right)$, pooled, and ground in a cutting mill (Type SM 100, Retsch GmbH, Haan, Germany) through a $0.5-\mathrm{mm}$ sieve and stored for chemical analyses. For analysis of inositol phosphates (InsPs), samples were pulverized in a vibrating cup mill (Type 6-TOPF, Siebtechnik GmbH, Mühlheim an der Ruhr, Germany). Housing, diets, and incubation procedure were in accordance with the German Animal Welfare Regulations and approved by the Regierungspräsidium Stuttgart, Germany.

\section{In Situ Procedure}

The incubation procedure was based on the recommendations for a standardized method for protein degradation of concentrate feeds (Madsen and Hvelplund, 1994). We prepared 5 different concentrates for ruminal incubation (Table 2). Soybean meal, solvent-extracted RSM without or with heat treatment for $60 \mathrm{~min}$ at $135^{\circ} \mathrm{C}$ (hRSM), wheat, and corn were ground in a cut- ting mill (Type SM 100) through a 2-mm sieve and stored at $6^{\circ} \mathrm{C}$ until incubation. For chemical analyses, the concentrates were pulverized in a vibrating cup mill (Type 6-TOPF). Feed samples were placed in polyester bags $(10.5 \times 20 \mathrm{~cm}, 50-\mu \mathrm{m}$ pore size, Type R510, Ancom Technology, Macedon, NY) and incubated in the rumen for $2,4,8,16$, and $24 \mathrm{~h}$. As the ruminal DM disappearance of the incubated concentrates differs, the amount of concentrate placed in the polyester bags was varied to gain sufficient bag residues for DM, CP, P, and InsPs analysis. In earlier studies (H. Steingass, unpublished data), we did not identify an effect of sample size on DM disappearance from concentrates under conditions where the sample weight approximated that recommended by Madsen and Hvelplund (1994), as was the case in the present study. Considering that an increase of sample weight was obtained by the addition of a low volume of concentrate, no interference with mixing and removal of bag contents was assumed. We placed $6 \mathrm{~g}$ of SBM, RSM, hRSM, or corn in the polyester bags for the 2 and $4 \mathrm{~h}$ of incubation, $8 \mathrm{~g}$ for $8 \mathrm{~h}$ of incubation, and $10 \mathrm{~g}$ for 16 and $24 \mathrm{~h}$ of incubation. For wheat, $10 \mathrm{~g}$ were weighed into the nylon bags for all incubation times. A total of 25 bags were attached to an anchor weight $(1 \mathrm{~kg})$ per incubation time and cow. We conducted 2 incubation runs for $16 \mathrm{~h}$ (SBM and wheat) and for $24 \mathrm{~h}$ (SBM, RSM, wheat, and corn) of incubation. For each cow in each period, bags from different concentrates of the same incubation time were incubated together. The incubation order of bags of different incubation times was assumed to be chosen at random for each cow and period. The bags were soaked

Table 2. Chemical composition of the incubated concentrates in $\mathrm{g} / \mathrm{kg}$ of DM (with $\%$ of total $\mathrm{P}$ in parentheses)

\begin{tabular}{|c|c|c|c|c|c|}
\hline \multirow[b]{2}{*}{ Item } & \multicolumn{5}{|c|}{ Concentrate $^{1}$} \\
\hline & SBM & RSM & hRSM & Wheat & Corn \\
\hline $\mathrm{CP}$ & 505 & 362 & 374 & 140 & 94.3 \\
\hline Total P & 6.43 & 13.0 & 13.6 & 3.88 & 2.88 \\
\hline $\operatorname{InsP}_{6}$ & 11.4 & 20.5 & 15.9 & 7.15 & 7.47 \\
\hline $\mathrm{InsP}_{5}$ & 2.23 & 2.83 & 8.39 & 0.43 & - \\
\hline $\mathrm{InsP}_{4}$ & $\underline{-}^{2}$ & - & 3.20 & - & - \\
\hline $\mathrm{InsP}_{3}$ & - & - & 1.31 & - & - \\
\hline $\mathrm{InsP}_{6}-\mathrm{P}^{3}$ & $3.22(50.1)$ & $5.77(44.4)$ & $4.49(33.0)$ & $2.01(51.8)$ & $2.10(72.9)$ \\
\hline $\operatorname{InsP}_{5}-\mathrm{P}^{3}$ & $0.60(9.3)$ & $0.76(5.9)$ & $2.24(16.5)$ & $0.11(2.8)$ & - \\
\hline $\mathrm{InsP}_{4}-\mathrm{P}^{3}$ & - & - & $0.79(5.8)$ & - & - \\
\hline $\mathrm{InsP}_{3}-\mathrm{P}^{3}$ & - & - & $0.29(2.1)$ & - & - \\
\hline $\operatorname{Ins}(1,2,4,5,6) \mathrm{P}_{5}$ & 1.30 & 1.29 & 3.73 & 0.24 & - \\
\hline $\operatorname{Ins}(1,2,3,4,5) \mathrm{P}_{5}$ & 0.58 & 0.92 & 2.71 & 0.13 & - \\
\hline $\operatorname{Ins}(1,2,3,4,6) \mathrm{P}_{5}$ & 0.25 & 0.50 & 1.52 & 0.06 & - \\
\hline $\operatorname{Ins}(1,3,4,5,6) \mathrm{P}_{5}$ & 0.10 & 0.12 & 0.43 & - & - \\
\hline
\end{tabular}


in warm water (approximately $39^{\circ} \mathrm{C}$ ) for $10 \mathrm{~min}$ before inserting them into the ventral sac of the rumen.

After removal from the rumen, the bags were immediately immersed in ice water to minimize further microbial fermentation. The bags were then rinsed with cold tap water to remove adhering feed particles and afterward washed in a washing machine for $20 \mathrm{~min}(2$ cycles of rinsing without spinning, each cycle including 1 water exchange). Afterward, the bags were immediately frozen at $-20^{\circ} \mathrm{C}$ and subsequently lyophilized. The bag residues were pooled for each incubation time and cow, pulverized in a vibrating cup mill (Type 6-TOPF), and stored at $4^{\circ} \mathrm{C}$ until analysis. This resulted in 3 independent samples per concentrate, incubation time, and diet.

\section{Chemical Analyses}

Crude nutrients were analyzed according to the official methods in Germany (VDLUFA, 1976). Dry matter (method 3.1) and CP (method 4.14.1) were analyzed in the diets, concentrates, and bag residues. Ash (method 8.1) and crude fiber (method 6.1.1) were analyzed in the diets as well.

For analysis of $\mathrm{P}$, samples were decomposed by wet digestion according to Boguhn et al. (2009) with slight modifications as described previously (Haese et al., 2014). In brief, the sample was heated in a block digestion system (Behr, K 20 L, Behr Labor-Technik GmbH, Düsseldorf, Germany) with sulfuric and nitric acid. The $\mathrm{P}$ concentration was measured in the filtered extracts by inductively coupled plasma optical emission spectrometry (Vista Pro, Varian Inc., Palo Alto, CA) at $213.618 \mathrm{~nm}$ wavelength.

The $\mathrm{InsP}_{6}$ and isomers of InsPs in the diets, concentrates, and bag residues were analyzed according to Zeller et al. (2015). In brief, $1 \mathrm{~g}$ of sample was extracted twice with a solution containing $0.2 M$ EDTA and 0.1 $M \mathrm{NaF}(\mathrm{pH}=10)$ and centrifuged $(12,000 \times g, 15$ min, $<6^{\circ} \mathrm{C}$ ). Three glass beads (diameter $0.6 \mathrm{~mm}$ ) were added to the sample before resuspending the pellet for the second extraction. The supernatants of both extractions were pooled, centrifuged $(14,000 \times g, 15$ min, $\left.<6^{\circ} \mathrm{C}\right)$, filtered $(0.2-\mu \mathrm{m}$ cellulose acetate filter, Macherey-Nagel GmbH \& Co. KG, Düren, Germany) into an Amicon ultra centrifugal filter tube $(0.5 \mathrm{~mL}$, $30 \mathrm{~K}$; Merck Millipore, Billerica, MA), and centrifuged $\left(14,000 \times g, 30 \mathrm{~min},<6^{\circ} \mathrm{C}\right)$ again. Filtrates were analyzed by high-performance ion chromatography (Dionex ICS 3000, Dionex Corp., Sunnyvale, CA). The $\mathrm{InsP}_{6}$ and the isomers of $\mathrm{InsP}_{5}, \mathrm{InsP}_{4}$, and $\mathrm{InsP}_{3}$ were separated; InsP-P concentrations were calculated from the respective analyzed $\mathrm{InsP}$ concentrations $\left(\mathrm{InsP}_{6} \times\right.$ $0.1858 ; \operatorname{InsP}_{5} \times 0.1549 ; \operatorname{InsP}_{4} \times 0.1239 ;$ and $\operatorname{InsP}_{3} \times$ $0.0929)$.

\section{Statistical Analysis}

The disappearance of $\mathrm{InsP}_{6}, \mathrm{P}$, and $\mathrm{CP}$ from the bags (y) was calculated as

$$
y(\%)=100-\frac{y_{\text {bag residue }}}{y_{\text {feed }}} \times 100
$$

where $y_{\text {bag residue }}$ is the analyzed concentration of $\operatorname{InsP}_{6}, \mathrm{P}$, or $\mathrm{CP}$ in the bag residue multiplied with the quantity of bag residue in the nylon bags, and $y_{\text {feed }}$ is the analyzed concentration of $\operatorname{InsP}_{6}, \mathrm{P}$, or $\mathrm{CP}$ in the concentrate multiplied with the quantity of incubated feedstuff.

We analyzed the data using the PROC MIXED feature of SAS analysis software (version 9.2, SAS Institute Inc., Cary, NC) followed by evaluation with the following model:

$$
\begin{gathered}
y_{i j k l m}=\mu+\alpha_{i}+\beta_{j}+\gamma_{k}+(\alpha \beta)_{i j}+(\alpha \gamma)_{i k}+(\beta \gamma)_{j k} \\
+(\alpha \beta \gamma)_{i j k}+\delta_{l}+\tau_{m}+(\delta \tau)_{l m}+(\gamma \delta \tau)+(\beta \delta \tau)+e_{i j k l m},
\end{gathered}
$$

where $y_{i j k l m}$ represents the observation of the $i$ th diet, the $j$ th concentrate, the $k$ th incubation time of cow $l$ in period $m ; \mu$ is the intercept; $\alpha_{i}$ is the fixed effect of diet $i(i=1$ to 3$) ; \beta_{j}$ is the fixed effect of concentrate $j(j=$ SBM, RSM, hRSM, wheat, corn); $\gamma_{k}$ is the fixed effect of incubation time $k(k=2,4,8,16,24 \mathrm{~h}) ; \delta_{l}$ is the random effect of cow $l(l=1$ to 3$) ; \tau_{m}$ is the random effect of period $m(m=1$ to 3$)$; and $e_{i j k l m}$ is the residual error of $y_{i j k l m}$. Interaction effects or hierarchical block effects are denoted by parentheses around the corresponding main effects.

Residuals were checked for normal distribution and if necessary, the data were transformed using a square root, logarithmic, or logit-transformation. As data for disappearance included zeros, the logit-transformation was slightly modified as

$$
\operatorname{logit}(y)=\log \frac{y+0.005}{1-y+0.005} .
$$

Additionally, the model was fitted with homogeneous and heterogeneous residual error variance for each concentrate. The model with the best covariance structure was selected depending on the Akaike information criterion (Wolfinger, 1996). Groups of samples measured at sequential time points represent repeated measures 
of the same rumen, thus requiring fitting by using an unstructured variance-covariance structure. However, replacing this structure by a compound symmetry structure resulted in a better model fit. Therefore, we used a compound symmetry structure for modeling the correlation between time points.

Statistical significance was declared at $P<0.05$. A significant F-test was followed by $t$-tests to show the individual significant differences. Data are presented as the least squares means and pooled standard error of means.

\section{RESULTS AND DISCUSSION}

\section{Differences in Ins $P_{6}$ Disappearance Between Concentrates}

After $24 \mathrm{~h}$ of incubation, $\geq 95 \%$ of $\mathrm{InsP}_{6}$ had disappeared from all concentrates (Table 3) except hRSM (57\%, diet average). Corn exhibited the highest $\mathrm{InsP}_{6}$ disappearance followed by wheat, SBM, RSM, and hRSM during the entire incubation process. After 2 and $4 \mathrm{~h}$ of incubation, however, $\operatorname{InsP}_{6}$ disappearance from RSM was lower compared with hRSM. The order of $\mathrm{InsP}_{6}$ disappearance from the various concentrates was in accordance with that reported by other studies (Konishi et al., 1999; Park et al., 1999; Blaabjerg et al., 2010; Brask-Pedersen et al., 2011; Haese et al., 2016) and can be ascribed to the localization and storage form of $\mathrm{InsP}_{6}$ in the respective seeds.

The predominant cations associated with $\mathrm{InsP}_{6}$ in corn are K and Mg (O'Dell, 1972). Potassium phytates are generally very soluble (Cheryan, 1980) because monovalent cations can be solubilized over the full $\mathrm{pH}$ spectrum (Adeola and Sands, 2003). The solubility of $\mathrm{Mg}$ phytates is dependent on the $\mathrm{pH}$ value; at $\mathrm{pH} 6.5$, $\mathrm{Mg}$ phytates are highly soluble (Jackman and Black, 1951). Accordingly, the physiological $\mathrm{pH}$ values in the rumen are considered to represent ideal conditions for high solubility of $\mathrm{Mg}$ phytates. Furthermore, the localization of $\mathrm{InsP}_{6}$ in the kernel is beneficial to rapid InsP $_{6}$ disappearance, as almost $90 \%$ of InsP $_{6}$ in corn is located in the germ (O'Dell, 1972) and grinding of the kernel promotes the contact between enzyme and substrate (Ton $\mathrm{Nu}$ et al., 2014).

In wheat, the major proportion of $\operatorname{InsP}_{6}$ is located in the aleurone layer (87\%; O'Dell, 1972), which mainly consists of nonstarch polysaccharides (Steenfeldt et al., 1995; Regvar et al., 2011; Pekkinen et al., 2014). The main minerals found in the $\mathrm{InsP}_{6}$ containing grain fractions in wheat are also $\mathrm{K}$ and $\mathrm{Mg}$ (O'Dell, 1972; Bohn et al., 2008). However, the higher Ca content than that of corn (O'Dell, 1972) suggests the presence of Ca phytates in wheat, which become insoluble at $\mathrm{pH}>6$ (Jack-

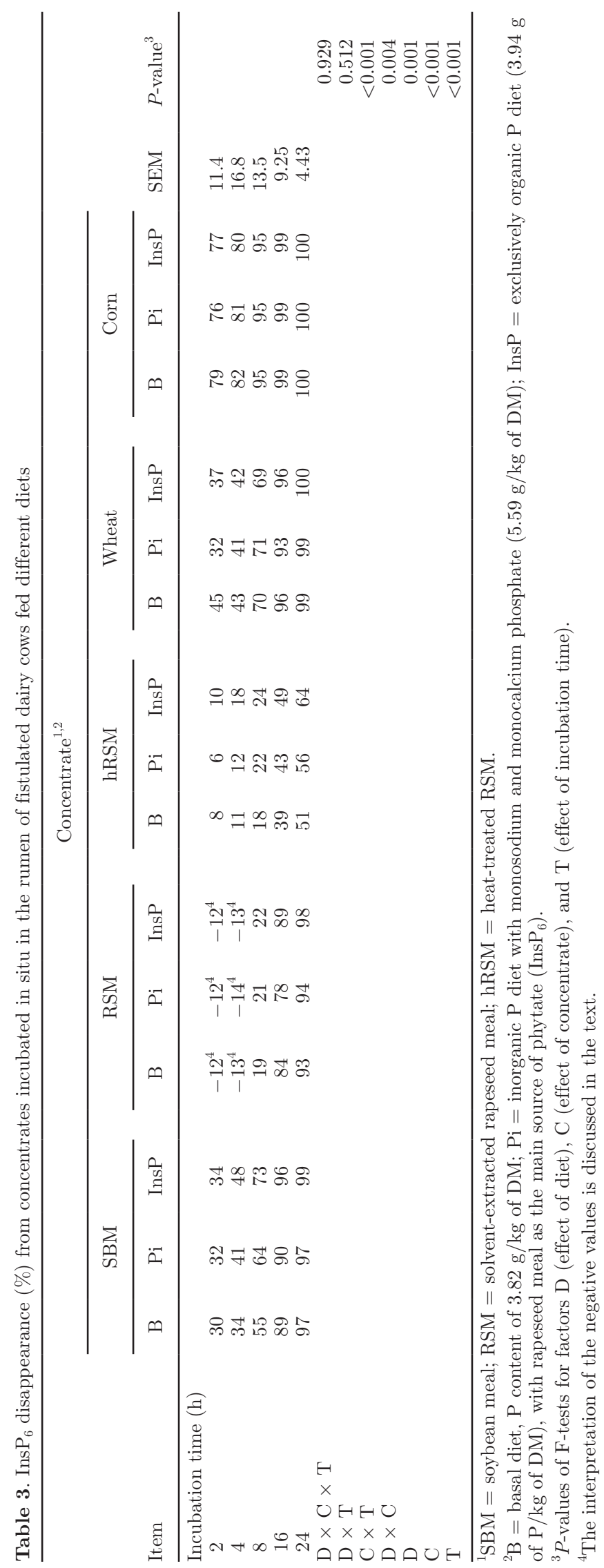


man and Black, 1951). Wheat and corn differ further in the structure of their PSV. In most seeds, $\operatorname{InsP}_{6}$ is concentrated inside the PSV, forming globoids (Lott, 1980; Gillespie et al., 2005); globoids occur only infrequently in corn, but are common in wheat (Lott, 1980). The degradation of $\mathrm{InsP}_{6}$ stored in globoids might be slower compared with that in the matrix, as phytases have no immediate access to the substrate.

In soybeans (Brooks and Morr, 1982) and rapeseed (Gillespie et al., 2005), $\operatorname{InsP}_{6}$ is tightly associated with protein and capable of binding these in binary complexes (Selle et al., 2012). In protein-phytate complexes, the $\mathrm{Ins}_{6}$ is likely shielded by its aggregated proteins (Selle et al., 2012). Therefore, enzymatic protein degradation appears to be a prerequisite for $\mathrm{InsP}_{6}$ hydrolysis from such complexes, which slows down the rate of $\mathrm{InsP}_{6}$ disappearance in the first few hours of incubation; however, $\mathrm{InsP}_{6}$ disappearance from SBM proceeded faster than that from RSM (Table 3). In addition to a high amount of highly soluble K phytates (Cheryan, 1980; Lott, 1980) compared with mainly $\mathrm{Mg}$ and Ca phytates in RSM (Gillberg and Törnell, 1976), soybeans differ from many other oilseeds and cereals, as their $\operatorname{InsP}_{6}$ is not located in globoids but is evenly distributed in the PSV (Tombs, 1967). This indicates that $\mathrm{InsP}_{6}$ in SBM is more accessible to phytase once protein degradation is in progress. Rapeseed PSV, however, are found throughout the seed in the aleurone layer, the cotyledons, and the radicle, and $\operatorname{InsP}_{6}$ stays associated with the denatured protein mass that is formed during the production of RSM (Yiu et al., 1983). These conditions suggest that, in RSM, enzymatic degradation of other cell and seed components is required before phytase can access $\mathrm{InsP}_{6}$ and initiate hydrolysis. This requirement might explain the distinct increase of $\mathrm{InsP}_{6}$ concentration that occurred in the bag residues of RSM during the first hours of incubation (data not shown). Along with the observed low disappearance of DM in RSM (data not shown), this led to negative disappearance values after 2 and $4 \mathrm{~h}$ of incubation (Table 3). Compared with RSM, InsP ${ }_{6}$ disappearance from hRSM was higher in the initial phase of incubation but remained lower at later incubation times. This might be due to a better accessibility of phytase to $\mathrm{InsP}_{6}$ in hRSM caused by structural changes of the protein-phytate complex that developed during the excessive heat treatment (Blaabjerg et al., 2007). For example, some $\mathrm{InsP}_{6}$ from a protein-phytate complex in which $\mathrm{InsP}_{6}$ is shielded by the aggregated protein might become more accessible to phytase when the protein is denatured and thus could be readily degraded. On the other hand, some $\mathrm{InsP}_{6}$ appears to be enclosed in the denatured protein and remains unavailable for ruminal degradation along with the RUP fraction.

\section{Influence of Diet on Ins $P_{6}$ Disappearance from Concentrates}

No interaction occurred between diet, concentrate, and time $(P=0.929$, Table 3$)$; however, interactions between concentrate and time $(P<0.001)$ and diet and concentrate $(P=0.004)$ were observed. Whereas feeding different diets did not influence $\mathrm{InsP}_{6}$ disappearance from wheat and corn, $\mathrm{InsP}_{6}$ disappearance differed between diets for SBM, RSM, and hRSM. Feeding the InsP diet increased $\mathrm{InsP}_{6}$ disappearance compared with the basal and Pi diets (SBM: 70 vs. 61 and 65\%; RSM: 37 vs. 34 and 33\%; hRSM: 33 vs. 26 and $28 \%$, respectively; time average). Comparable in situ studies on this topic are lacking; however, previous studies observed similar effects in vivo and in vitro (Ray et al., 2013; Haese et al., 2014, 2016). In particular, Lan et al. (2002) suggested that phytate is responsible for inducing phytase production by the rumen bacterium Mitsuokella jalaludinii. Thus, feeding the InsP diet might have induced phytase production of rumen microorganisms in the current study, resulting in a higher $\mathrm{InsP}_{6}$ disappearance from oilseed meals compared with the basal and $\mathrm{Pi}$ diets. The $\mathrm{InsP}_{6}$ disappearance from wheat and corn, however, did not increase with the InsP diet. Owing to the generally high native susceptibility of wheat and corn phytate to hydrolysis and the markedly lower $\mathrm{InsP}_{6}$ concentrations of wheat and corn than those of oilseed meals, the phytase activity achieved with the basal diet was assumed to be sufficient for maximal $\mathrm{InsP}_{6}$ disappearance.

Adding inorganic $\mathrm{P}$ to the diet did not influence $\mathrm{InsP}_{6}$ disappearance from any concentrate. Inorganic phosphates are known to suppress phytase production from Aspergillus ficuum (Shieh et al., 1969; Howson and Davis, 1983) and other species of molds and yeasts (Shieh and Ware, 1968). However, ruminal phytase-producing bacteria proved to be less affected by phosphates, as no inhibition of phytase activity was detected even at high phosphate concentrations in the medium (Yanke et al., 1998; Lan et al., 2011). The results of the current study support the statement of Yanke et al. (1998) that the inhibition of phytase activity by phosphate in ruminal bacteria appears unlikely as high levels of phosphate occur normally in the rumen.

\section{P Disappearance}

No significant interaction was found between diet, concentrate, and time $(P=0.469)$; the InsP diet, however, exhibited higher $\mathrm{P}$ disappearance compared with the basal and Pi diets (70 vs. 68 and $67 \%$, concentrate and time average; $P=0.002$ ). The $\mathrm{P}$ disappearance from the concentrates, averaged over the diets, is presented 


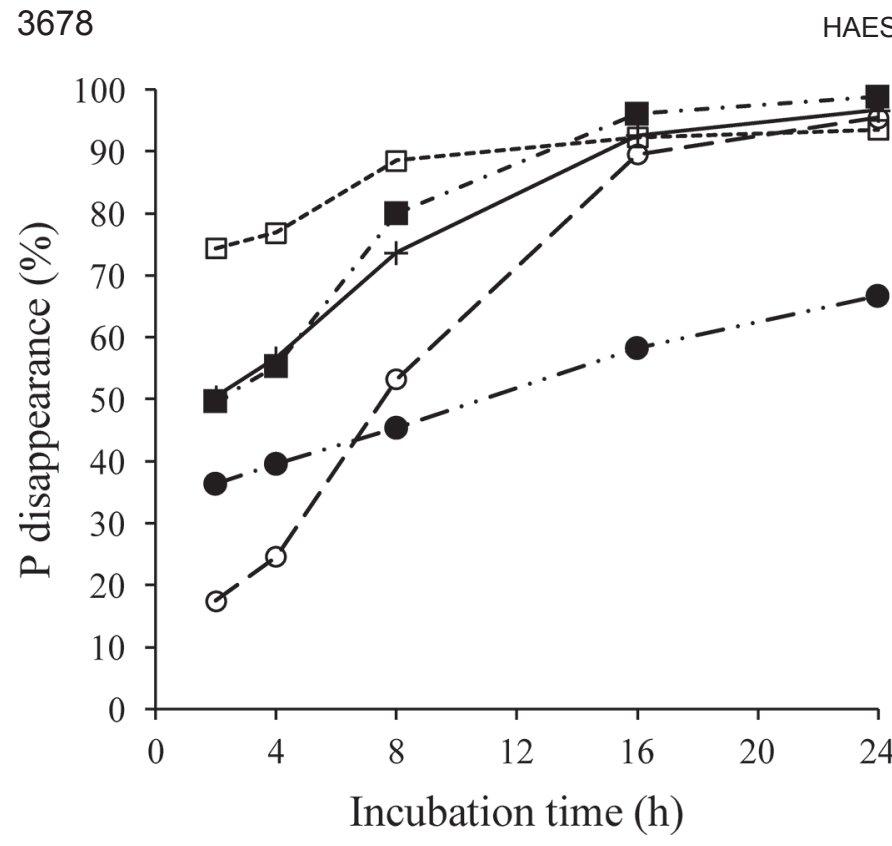

Figure 1. Phosphorus disappearance from concentrates incubated in situ in the rumen of fistulated dairy cows. ( $\square$ ) Wheat; ( $\square$ ) corn; $(+)$ soybean meal; $(\bigcirc)$ rapeseed meal (RSM); $(\bullet)$ heat-treated RSM.

in Figure 1. After $24 \mathrm{~h}$ of incubation, $\mathrm{P}$ disappearance was $>90 \%$ for all concentrates except hRSM $(67 \%)$. The disappearance of $\mathrm{P}$ proceeded faster compared with the $\mathrm{InsP}_{6}$ disappearance, which probably can be ascribed to a faster degradation rate of lower InsPs and other P-containing compounds such as phospholipids or $\mathrm{P}$ bound to nucleic acids.

\section{CP Disappearance and Correlation with Ins $P_{6}$ Disappearance}

For the disappearance of $\mathrm{CP}$, no interaction between diet, concentrate, and time $(P=0.413)$ occurred and no influence of feeding different diets was observed $(P$ $=0.346)$. After $24 \mathrm{~h}$ of incubation, $97 \%$ of $\mathrm{CP}$ from wheat (diet average), 93\% from SBM, 90\% from RSM, $67 \%$ from corn, and $47 \%$ from hRSM had disappeared (Figure 2).

To evaluate correlations between $\mathrm{CP}$ and $\mathrm{InsP}_{6}$ disappearance from concentrates, linear regressions were performed for each concentrate. Figure 3 shows the regressions for the incubated oilseed meals, which exhibited higher coefficients of determination than the cereal grains (SBM: $\mathrm{y}=0.916 \mathrm{x}+14.85 ; \mathrm{R}^{2}=0.93 ; \mathrm{RSM}$ : $\mathrm{y}=$ $1.839 \mathrm{x}-73.57 ; \mathrm{R}^{2}=0.97$; hRS $: \mathrm{y}=1.603 \mathrm{x}-18.80$; $\mathrm{R}^{2}=0.93$; wheat: $\mathrm{y}=1.087 \mathrm{x}-13.0 ; \mathrm{R}^{2}=0.83$; corn: $\mathrm{y}$ $\left.=0.581 \mathrm{x}+63.80 ; \mathrm{R}^{2}=0.70\right)$. The high coefficients of determination between $\mathrm{CP}$ and $\mathrm{InsP}_{6}$ disappearance for oilseed meals compared with wheat and corn reflect the existence of protein-phytate complexes within the PSV in the oilseed meals. The results suggest that the disappearance of $\mathrm{InsP}_{6}$ is strongly dependent on CP disappearance, especially in RSM. Further heat treatment of RSM appeared to partially reduce this dependency as the structural changes in the protein-phytate complexes render some $\mathrm{InsP}_{6}$ more accessible to phytases, as discussed above.

\section{Ins $P_{5}$ Isomer Concentrations}

Data for $\mathrm{InsP}_{5}$ isomers are presented as concentrations because $\mathrm{InsP}_{5}$ is both formed from $\mathrm{InsP}_{6}$ and degraded to $\mathrm{InsP}_{4}$ over the course of incubation, thus making it impossible to calculate a discrete disappearance rate for $\mathrm{InsP}_{5}$. Bag residues of corn contained no $\mathrm{InsP}_{5}$, whereas 3 different $\operatorname{InsP}_{5}$ isomers $[\operatorname{Ins}(1,2,4,5,6)$ $\mathrm{P}_{5}$, Ins $(1,2,3,4,5) \mathrm{P}_{5}$, and $\left.\operatorname{Ins}(1,2,3,4,6) \mathrm{P}_{5}\right]$ were detected in the bag residues of SBM, RSM, hRSM, and wheat. The bag residues of RSM and hRSM also contained an additional $\operatorname{InsP}_{5}$ isomer $\left[\operatorname{Ins}(1,3,4,5,6) \mathrm{P}_{5}\right]$. At early incubation times, the $\operatorname{Ins}_{5}$ isomers originally contained in the concentrates assumedly contributed to the concentration of the $\mathrm{InsP}_{5}$ isomers in the bag residues. However, $\mathrm{InsP}_{6}$ disappearance was already observed after 2 $\mathrm{h}$ of incubation (except for RSM), which indicates that $\mathrm{InsP}_{5}$ isomers originated from $\mathrm{InsP}_{6}$ hydrolysis during the early incubation times as well.

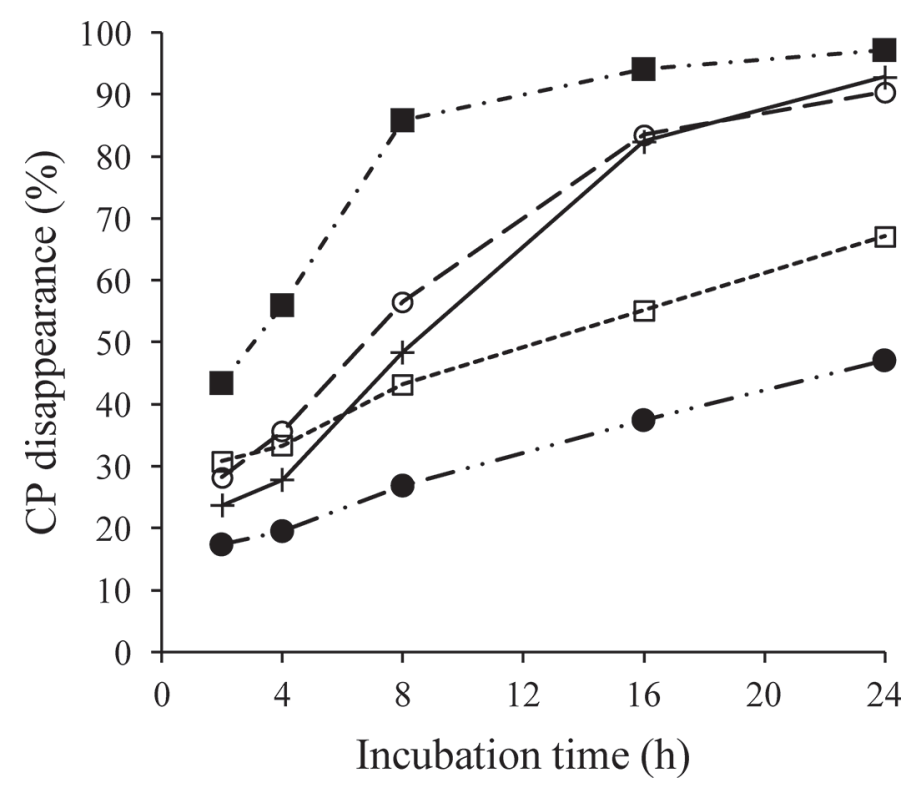

Figure 2. Crude protein disappearance from concentrates incubated in situ in the rumen of fistulated dairy cows. (ם) Wheat; $(\square)$ corn; $(+)$ soybean meal; $(\bigcirc)$ rapeseed meal $(\mathrm{RSM}) ;(\bullet)$ heat-treated RSM. 
The predominant $\operatorname{InsP}_{5}$ isomers in all bag residues at any incubation time were $\operatorname{Ins}(1,2,4,5,6) \mathrm{P}_{5}$ (Table 4 ) and $\operatorname{Ins}(1,2,3,4,5) \mathrm{P}_{5}$ (Table 5), the hydrolysis products of 3- and 6-phytases, respectively. Feeding InsP led to a lower concentration of $\operatorname{Ins}(1,2,4,5,6) \mathrm{P}_{5}$ compared with the basal and $\mathrm{Pi}$ diets (2.76 vs. 3.04 and $2.97 \mathrm{~g} / \mathrm{kg}$ of DM, respectively; concentrate and time average; $P$ $=0.003)$. Similar effects occurred for $\operatorname{Ins}(1,2,3,4,5) \mathrm{P}_{5}$ (InsP $=2.02 \mathrm{~g} / \mathrm{kg}$ of DM; basal $=2.25 \mathrm{~g} / \mathrm{kg}$ of DM; Pi $=2.18 \mathrm{~g} / \mathrm{kg}$ of DM; concentrate and time average; $P$ $=0.001)$. Thus, the observed increase in $\mathrm{InsP}_{6}$ disappearance from oilseed meals when InsP was fed did not result in an accumulation of $\mathrm{InsP}_{5}$ isomers, but was accompanied by lower concentrations of $\operatorname{Ins}(1,2,4,5,6)$ $\mathrm{P}_{5}$ and $\operatorname{Ins}(1,2,3,4,5) \mathrm{P}_{5}$. This could indicate that the activity of the 3-and 6-phytases was influenced by the diet resulting in an increased hydrolysis of the respective $\mathrm{InsP}_{5}$ isomers.

To date, 3-phytases represent the largest group of phytases and are generally found in both fungi and bacteria (Bohn et al., 2008), whereas 6-phytases usually originate from plants (Cosgrove, 1970). However, 6-phytases are found in bacteria such as Escherichia coli (Greiner et al., 1993) and Bifidobacterium pseudocatenulatum (Haros et al., 2009) as well. In the current study, the $\operatorname{Ins}(1,2,3,4,5) \mathrm{P}_{5}$ concentrations were influenced by the diet, which suggests that microbial 6-phytase production (from the rumen) rather than endogenous plant phytases contributed to this hydrolysis product. Furthermore, wheat was the only examined concentrate exhibiting substantial endogenous phytase activity (Eeckhout and de Paepe, 1994; Rodehutscord et al., 2016); however, the percentage of $\operatorname{Ins}(1,2,3,4,5)$ $\mathrm{P}_{5}$ within total $\mathrm{InsP}_{5}$ in wheat differed only slightly, albeit significantly, from that of the other concentrates (36 vs. $31 \%$ in SBM, $33 \%$ in RSM, and $32 \%$ in hRSM).

The concentrations of $\operatorname{Ins}(1,2,3,4,6) \mathrm{P}_{5}$, indicating the possible activity of 5 -phytases in the rumen, showed an interaction between diet, concentrate, and time $(P=0.001$, Table 6$)$. At later incubation times, $\operatorname{Ins}(1,2,3,4,6) \mathrm{P}_{5}$ exhibited lower concentrations when cows were fed InsP $(\mathrm{SBM}=8 \mathrm{~h} ; \mathrm{RSM}=16 \mathrm{~h} ; \mathrm{hRSM}$ $=24 \mathrm{~h}$; wheat $=16 \mathrm{~h}$ ). To date, 5 -phytase has been detected only in lily pollen (Barrientos et al., 1994), Selenomonas ruminantium ssp. lactilytica (Puhl et al., 2008), and B. pseudocatenulatum (Haros et al., 2009). Notably, the 5-phytase from $S$. ruminantium ssp. lactilytica is expressed even when $\operatorname{InsP}_{6}$ in the medium is excluded (Puhl et al., 2008), indicating that its phytase activity may not generally be enhanced with more $\mathrm{InsP}_{6}$ in the rumen. The late onset of the diet effect on $\operatorname{Ins}(1,2,3,4,6) \mathrm{P}_{5}$ concentration in our study suggests that a connection exists between protein degradation in the first hours of incubation and the accessibility to further $\mathrm{InsP}_{6}$ from protein-phytate complexes at later incubation times. Therefore, the influence of the diet on the activity of 5-phytase might have become noticeable only after further substrate was accessible. This sug-

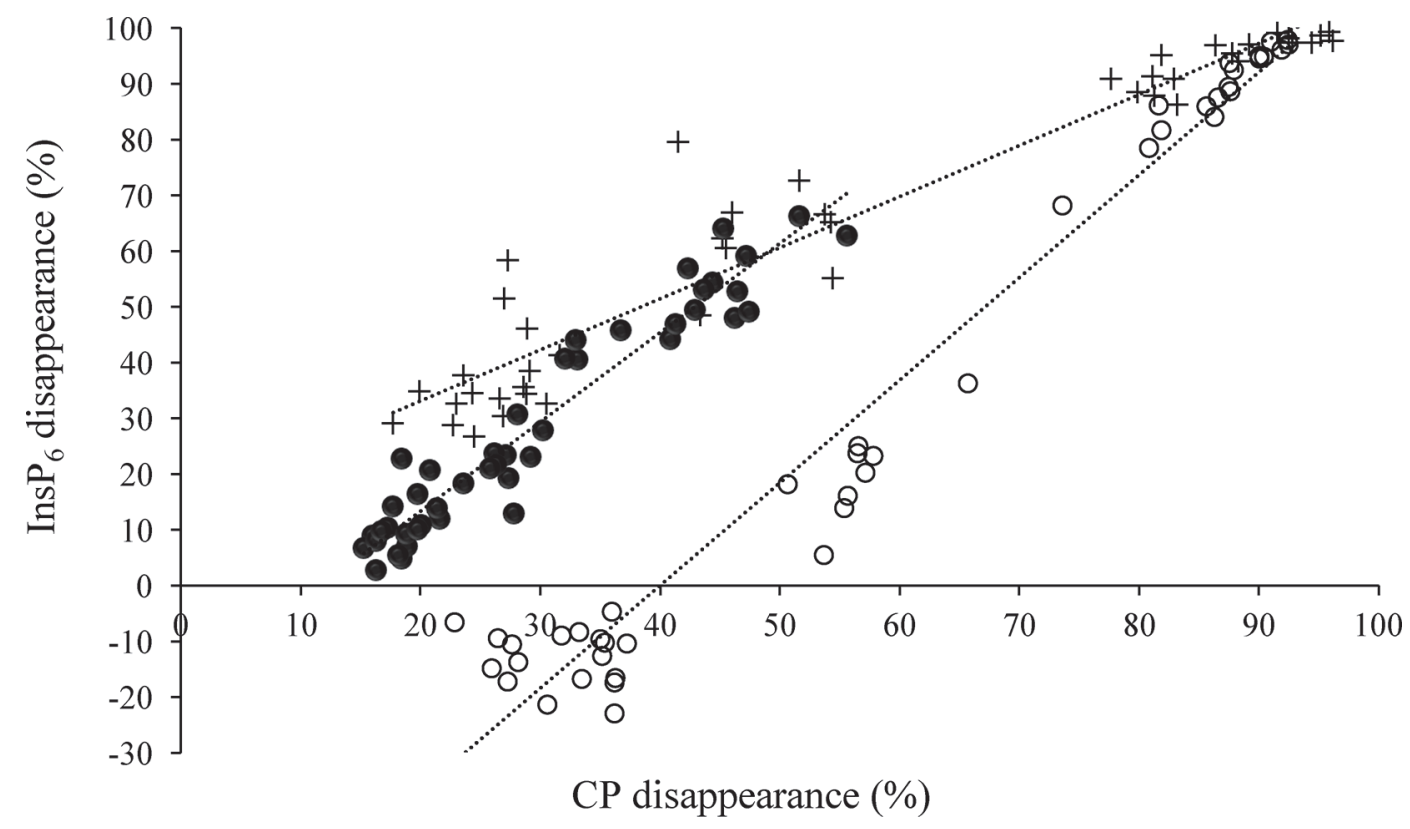

Figure 3. Linear regressions for $\mathrm{CP}$ and phytate $\left(\mathrm{InsP}_{6}\right)$ disappearance (in \%) for incubated oilseed meals. $(+)$ Soybean meal $(\mathrm{SBM})$, y $=$ $0.916 \mathrm{x}+14.85, \mathrm{R}^{2}=0.93 ;(\bigcirc)$ rapeseed meal $(\mathrm{RSM}), \mathrm{y}=1.839 \mathrm{x}-73.57, \mathrm{R}^{2}=0.97 ;(\bullet)$ heat-treated $\mathrm{RSM}, \mathrm{y}=0.1603 \mathrm{x}-18.80, \mathrm{R}^{2}=0.93$. 

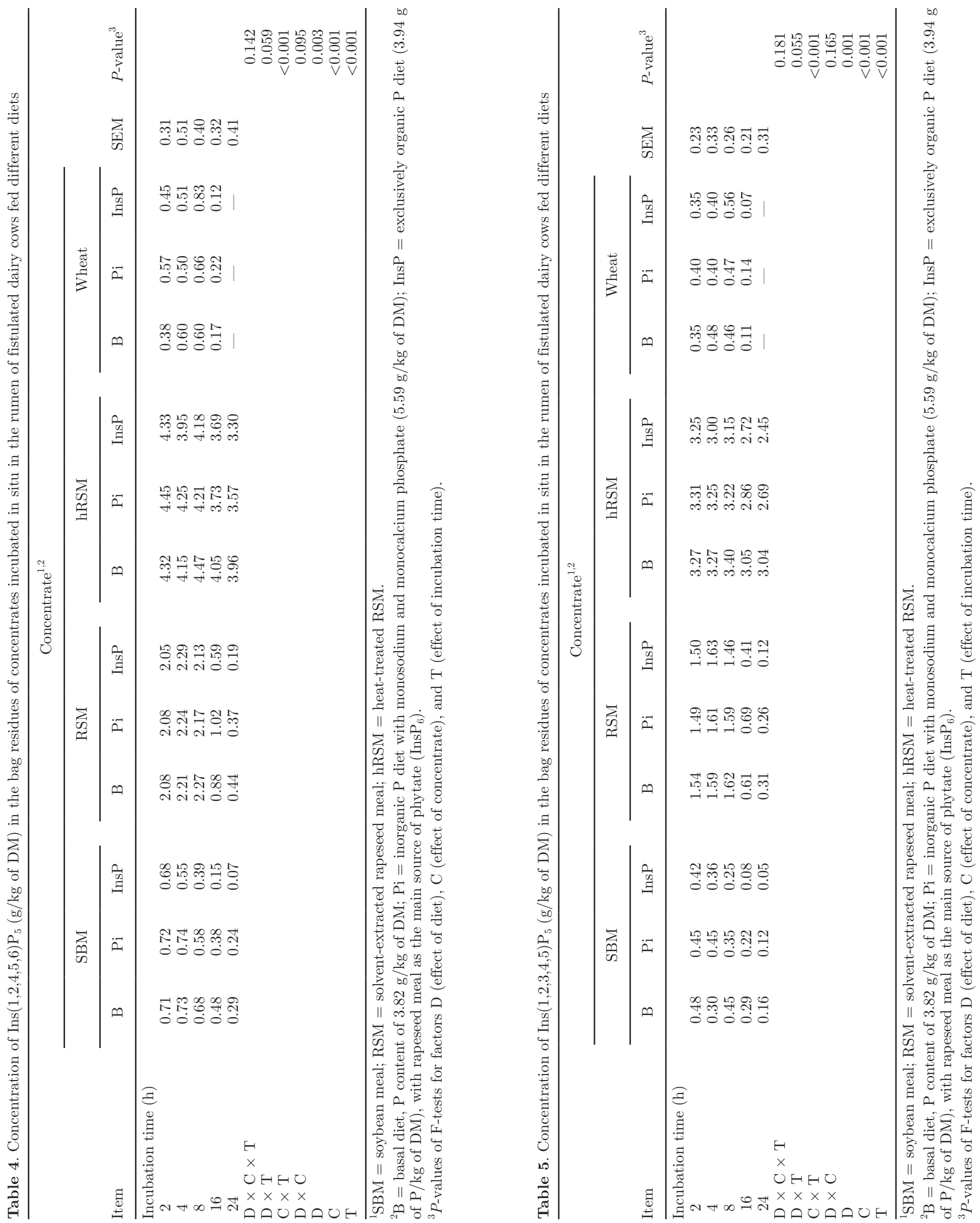


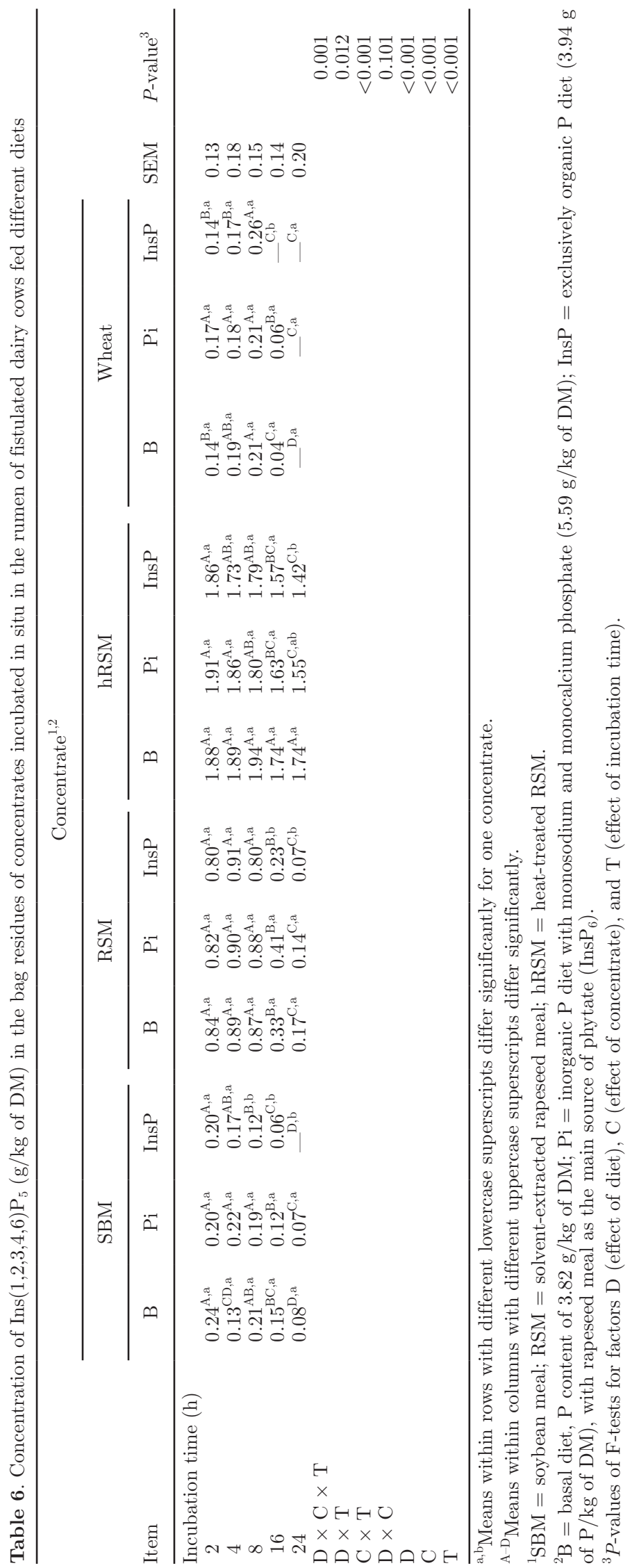


Table 7. Concentration of $\operatorname{Ins}(1,3,4,5,6) \mathrm{P}_{5}(\mathrm{~g} / \mathrm{kg}$ of $\mathrm{DM})$ in the bag residues of concentrates incubated in situ in the rumen of fistulated dairy cows fed different diets

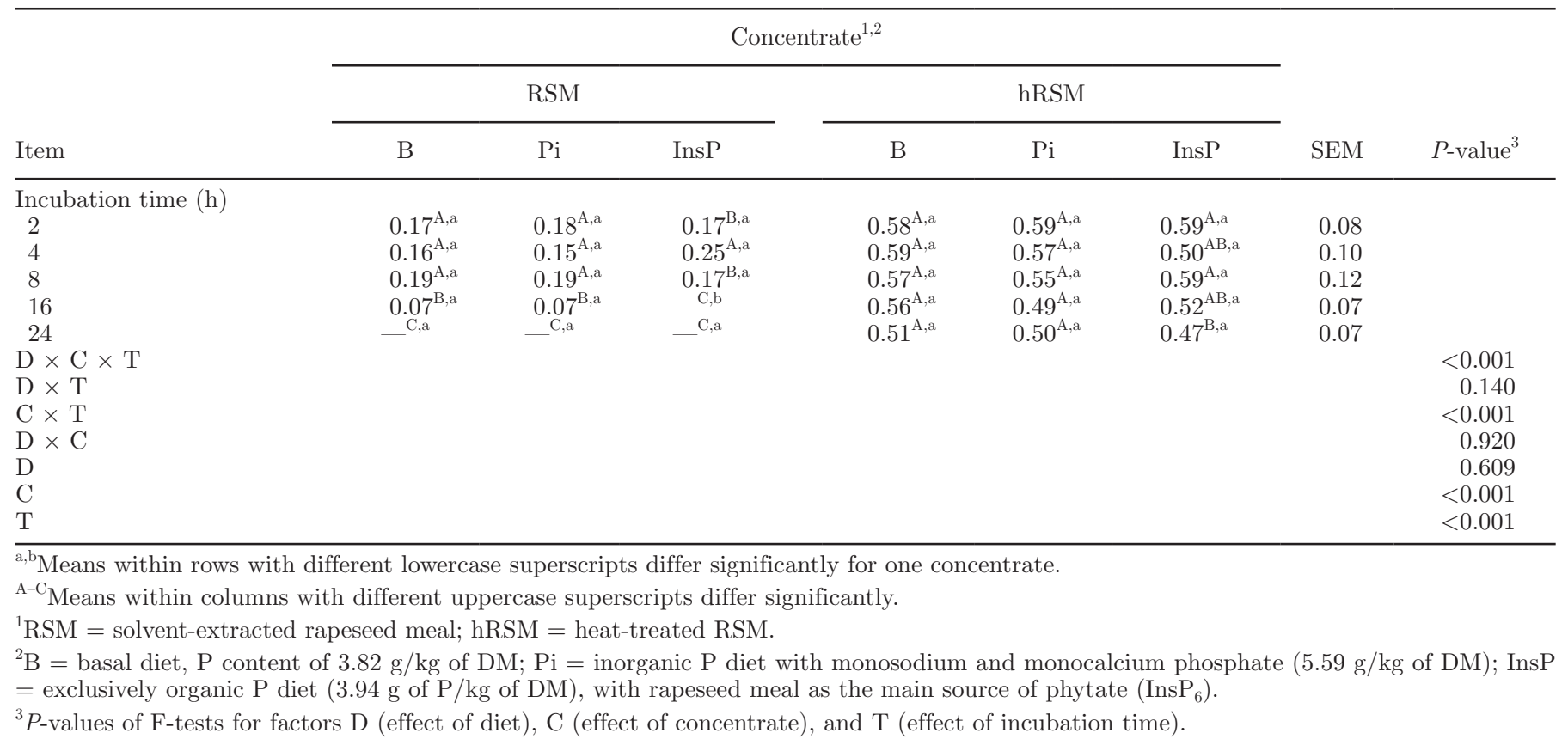

gestion might be supported by comparing the onset of the effect between the incubated oilseed meals, which occurred first for SBM $(8 \mathrm{~h})$ followed by RSM $(16 \mathrm{~h})$ and hRSM $(24 \mathrm{~h})$.

The $\operatorname{Ins}(1,3,4,5,6) \mathrm{P}_{5}$ was exclusively detected in the bag residues of RSM and hRSM and showed an interaction between diet, concentrate, and time as well $(P<$ 0.001; Table 7). To our knowledge, a 2-phytase has not been described to date and this isomer was found exclusively in oilseed meals and the bag residues of RSM and hRSM; thus, we assumed that this isomer was formed during the production process of the oilseed meals. This conclusion was strengthened by the observed differences between RSM and hRSM. Whereas the $\operatorname{Ins}(1,3,4,5,6) \mathrm{P}_{5}$ concentration was lower for RSM and had disappeared completely after $24 \mathrm{~h}$ of incubation, that in hRSM remained almost unchanged during the incubation procedure. The $\operatorname{Ins}(1,3,4,5,6) \mathrm{P}_{5}$ might be associated with the denatured RUP fraction of hRSM that arose during the additional heat treatment.

The presence of considerable concentrations of $\mathrm{InsP}_{4}$ and InsP $\mathrm{P}_{3}$ was only demonstrated in the bag residues of hRSM (data not shown); however, no accumulation of $\mathrm{InsP}_{4}$ and $\mathrm{InsP}_{3}$ was observed. This confirms the conclusions of in vitro studies, that the hydrolysis of the first phosphate group is the decisive step in InsP digestion and degradation of the lower InsPs follows promptly thereafter (Blaabjerg et al., 2007; Brask-Pedersen et al., 2011).

\section{CONCLUSIONS}

The degradability of $\mathrm{InsP}_{6}$ differs markedly between concentrates. In the rumen, oilseed meals and RSM in particular are hydrolyzed at a lower rate compared with cereals, although high $\operatorname{InsP}_{6}$ concentrations in the diet enhance their $\operatorname{InsP}_{6}$ hydrolysis in the rumen. This suggests that when oilseed meals comprise part of the diets for dairy cows, diet formulations should aim to achieve high $\operatorname{InsP}_{6}$ concentrations to increase ruminal $\mathrm{InsP}_{6}$ hydrolysis. Such modifications should be considered especially in diets for high-yielding cows with high DMI, as the reduced rumen retention times of the digesta might otherwise limit ruminal $\mathrm{InsP}_{6}$ hydrolysis. Furthermore, the disappearance of $\mathrm{InsP}_{6}$ from oilseed meals is influenced by the diet fed to the fistulated animals. This factor should be considered when ruminal $\mathrm{InsP}_{6}$ disappearance is examined in situ to allow for standardized procedures. Analysis of the $\mathrm{InsP}_{5}$ isomers indicates that endogenous plant phytase activity plays a minor role in the rumen. Thus, it is unlikely that an increase of ruminal $\mathrm{InsP}_{6}$ hydrolysis could be achieved in ruminants by increasing the amount of concentrates with high endogenous phytase activity in the diet. The active phytases in the rumen are likely differentially influenced by the diet composition. The actual phytase activity of microorganisms in the rumen is difficult to determine; however, to optimize $\mathrm{InsP}_{6}$ hydrolysis in the rumen, further studies should be conducted to obtain 
more information regarding phytase-producing microorganisms and the identity and characteristics of their respective phytases.

\section{ACKNOWLEDGMENTS}

The support of this study by Carl-Zeiss-Stiftung, Stuttgart, Germany, with a doctoral scholarship for Eva Haese, is gratefully acknowledged.

\section{REFERENCES}

Adeola, O., and J. S. Sands. 2003. Does supplemental dietary microbial phytase improve amino acid utilization? A perspective it does not. J. Anim. Sci. 81(E. Suppl. 2):78-85.

Barrientos, L., J. J. Scott, and P. P. N. Murthy. 1994. Specificity of hydrolysis of phytic acid by alkaline phytase from lily pollen. Plant Physiol. 106:1489-1495.

Blaabjerg, K., D. Carlson, J. Hansen-Møller, A.-H. Tauson, and H. D. Poulsen. 2007. In vitro degradation of phytate and lower inositol phosphates in soaked diets and feedstuffs. Livest. Sci. 109:240-243.

Blaabjerg, K., N.-G. Carlsson, J. Hansen-Møller, and H. D. Poulsen. 2010. Effect of heat-treatment, phytase, xylanase and soaking time on inositol phosphate degradation in vitro in wheat, soybean meal and rapeseed cake. Anim. Feed Sci. Technol. 162:123-134.

Boguhn, J., T. Baumgärtel, A. Dieckmann, and M. Rodehutscord. 2009. Determination of titanium dioxide supplements in different matrices using two methods involving photometer and inductively coupled plasma optical emission spectrometer measurements. Arch. Anim. Nutr. 63:337-342.

Bohn, L., A. S. Meyer, and S. K. Rasmussen. 2008. Phytate: Impact on environment and human nutrition. A challenge for molecular breeding. J. Zhejiang Univ. Sci. B 9:165-191.

Brask-Pedersen, D. N., L. V. Glits $\varnothing$, L. K. Skov, P. Lund, and J. Sehested. 2011. Effect of exogenous phytase on feed inositol phosphate hydrolysis in an in vitro rumen fluid buffer system. J. Dairy Sci. 94:951-959.

Brooks, J. R., and C. V. Morr. 1982. Phytate removal from soy protein isolates using ion exchange processing treatments. J. Food Sci. 47:1280-1282.

Cheryan, M. 1980. Phytic acid interactions in food systems. Crit. Rev. Food Sci. Nutr. 13:297-335.

Clark, W. D. Jr., J. E. Wohlt, R. L. Gilbreath, and P. K. Zajac. 1986. Phytate phosphorus intake and disappearance in the gastrointestinal tract of high producing dairy cows. J. Dairy Sci. 69:3151-3155.

Cosgrove, D. J. 1970. Inositol phosphate phosphatases of microbiological origin. Inositol phosphate intermediates in the dephosphorylation of the hexaphosphates of myo-inositol, scyllo-inositol, and D-chiro-inositol by a bacterial (pseudomonas sp.) phytase. Aust. J. Biol. Sci. 23:1207-1220.

Eeckhout, W., and M. de Paepe. 1994. Total phosphorus, phytatephosphorus and phytase activity in plant feedstuffs. Anim. Feed Sci. Technol. 47:19-29.

GfE. 2001. Gesellschaft für Ernährungsphysiologie. Empfehlungen zur Energie- und Nährstoffversorgung der Milchkühe und Aufzuchtrinder. DLG-Verlag, Frankfurt, Germany.

Gillberg, L., and B. Törnell. 1976. Preparation of rapeseed protein isolates. Dissolution and precipitation behavior of rapeseed proteins. J. Food Sci. 41:1063-1069.

Gillespie, J., S. W. Rogers, M. Deery, P. Dupree, and J. C. Rogers. 2005. A unique family of proteins associated with internalized membranes in protein storage vacuoles of the Brassicaceae. Plant J. 41:429-441.

Godoy, S., and F. Meschy. 2001. Utilisation of phytate phosphorus by rumen bacteria in a semi-continuous culture system (Rusitec) in lactating goats fed on different forage to concentrate ratios. Reprod. Nutr. Dev. 41:259-265.
Greiner, R., and U. Konietzny. 2006. Phytase for food application. Food Technol. Biotechnol. 44:125-140.

Greiner, R., U. Konietzny, and K.-D. Jany. 1993. Purification and characterization of two phytases from Escherichia coli. Arch. Biochem. Biophys. 303:107-113.

Haese, E., M. Lengowski, E. Gräter, A. Föll, J. Möhring, H. Steingass, M. Schollenberger, and M. Rodehutscord. 2016. Ruminal phytate degradation of maize grain and rapeseed meal in vitro and as affected by phytate content in donor animal diets and inorganic phosphorus in the buffer. J. Anim. Physiol. Anim. Nutr. https:// doi.org/10.1111/jpn.12500.

Haese, E., K. Müller, H. Steingass, M. Schollenberger, and M. Rodehutscord. 2014. Effects of mineral and rapeseed phosphorus supplementation on phytate degradation in dairy cows. Arch. Anim. Nutr. 68:478-491.

Haros, M., N.-G. Carlsson, A. Almgren, M. Larsson-Alminger, A.-S. Sandberg, and T. Andlid. 2009. Phytate degradation by human gut isolated Bifidobacterium pseudocatenulatum ATCC27919 and its probiotic potential. Int. J. Food Microbiol. 135:7-14.

Howson, S. J., and R. P. Davis. 1983. Production of phytate-hydrolysing enzyme by some fungi. Enzyme Microb. Technol. 5:377-382.

Jackman, R. H., and C. A. Black. 1951. Solubility of iron, aluminum, calcium, and magnesium inositol phosphates at different $\mathrm{pH}$ values. Soil Sci. 72:179-186.

Konishi, C., T. Matsui, W. Park, H. Yano, and F. Yano. 1999. Heat treatment of soybean meal and rapeseed meal suppresses rumen degradation of phytate phosphorus in sheep. Anim. Feed Sci. Technol. 80:115-122

Lan, G. Q., N. Abdullah, S. Jalaludin, and Y. W. Ho. 2002. Optimization of carbon and nitrogen sources for phytase production by Mitsuokella jalaludinii, a new rumen bacterial species. Lett. Appl. Microbiol. 35:157-161.

Lan, G. Q., N. Abdullah, S. Jalaludin, and Y. W. Ho. 2011. Purification and characterization of a phytase from Mitsuokella jalaludinii, a bovine rumen bacterium. Afr. J. Biotechnol. 10:12796-12806.

Lott, J. N. A. 1980. Protein bodies. Pages 589-623 in The Biochemistry of Plants, Volume 1: The Plant Cell. N. E. Tolbert, ed. Academic Press Inc., New York, NY.

Madsen, J., and T. Hvelplund. 1994. Prediction of in situ protein degradability in the rumen. results of a European ringtest. Livest. Prod. Sci. 39:201-212.

Martín-Tereso, J., A. Gonzalez, H. Van Laar, C. Burbano, M. M. Pedrosa, K. Mulder, L. A. den Hartog, and M. W. A. Verstegen. 2009. In situ ruminal degradation of phytic acid in formaldehydetreated rice bran. Anim. Feed Sci. Technol. 152:286-297.

Morse, D., H. H. Head, and C. J. Wilcox. 1992. Disappearance of phosphorus in phytate from concentrates in vitro and from rations fed to lactating dairy cows. J. Dairy Sci. 75:1979-1986.

O'Dell, B. L. 1972. Distribution of phytate and nutritionally important elements among the morphological components of cereal grains. J. Agric. Food Chem. 20:718-721.

O'Dell, B. L., and A. de Boland. 1976. Complexation of phytate with proteins and cations in corn germ and oilseed meals. J. Agric. Food Chem. 24:804-808.

Park, W.-Y., T. Matsui, C. Konishi, K. Sung-Won, F. Yano, and H. Yano. 1999. Formaldehyde treatment suppresses ruminal degradation of phytate in soyabean meal and rapeseed meal. Br. J. Nutr. 81:467-471.

Pekkinen, J., N. N. Rosa, O.-I. Savolainen, P. Keski-Rahkonen, H. Mykkänen, K. Poutanen, V. Micard, and K. Hanhineva. 2014 Disintegration of wheat aleurone structure has an impact on the bioavailability of phenolic compounds and other phytochemicals as evidenced by altered urinary metabolite profile of diet-induced obese mice. Nutr. Metab. (Lond.) 11:1. https://doi. org/10.1186/1743-7075-11-1.

Puhl, A. A., R. Greiner, and L. B. Selinger. 2008. A protein tyrosine phosphatase-like inositol polyphosphatase from Selenomonas ruminantium ssp. lactilytica has specificity for the 5-phosphate of myo-inositol hexakisphosphate. Int. J. Biochem. Cell Biol. 40:2053-2064. 
Raun, A., E. Cheng, and W. Burroughs. 1956. Ruminant nutrition: phytate phosphorus hydrolysis and availability to rumen microorganisms. J. Agric. Food Chem. 4:869-871.

Ray, P. P., J. Jarrett, and K. F. Knowlton. 2013. Effect of dietary phytate on phosphorus digestibility in dairy cows. J. Dairy Sci. 96:1156-1163.

Regvar, M., D. Eichert, B. Kaulich, A. Gianoncelli, P. Pongrac, K. Vogel-Mikuš, and I. Kreft. 2011. New insights into globoids of protein storage vacuoles in wheat aleurone using synchrotron soft X-ray microscopy. J. Exp. Bot. 62:3929-3939.

Rodehutscord, M., C. Rückert, H. P. Maurer, H. Schenkel, W. Schipprack, K. E. Bach Knudsen, M. Schollenberger, M. Laux, M. Eklund, W. Siegert, and R. Mosenthin. 2016. Variation in chemical composition and physical characteristics of cereal grains from different genotypes. Arch. Anim. Nutr. 70:87-107.

Selle, P. H., A. J. Cowieson, N. P. Cowieson, and V. Ravindran. 2012 Protein-phytate interactions in pig and poultry nutrition: A reappraisal. Nutr. Res. Rev. 25:1-17.

Shieh, T. R., and J. H. Ware. 1968. Survey of microorganism for the production of extracellular phytase. Appl. Microbiol. 16:1348 1351.

Shieh, T. R., R. J. Wodzinski, and J. H. Ware. 1969. Regulation of the formation of acid phosphatases by inorganic phosphate in Aspergillus ficuum. J. Bacteriol. 100:1161-1165.

Steenfeldt, S., K. E. B. Knudsen, C. F. Børsting, and B. O. Eggum. 1995. The nutritive value of decorticated mill fractions of wheat.
2. Evaluation with raw and enzyme treated fractions using adult cockerels. Anim. Feed Sci. Technol. 54:249-265.

Tombs, M. P. 1967. Protein bodies of the soybean. Plant Physiol. 42:797-813.

Ton Nu, M. A., K. Blaabjerg, and H. D. Poulsen. 2014. Effect of particle size and microbial phytase on phytate degradation in incubated maize and soybean meal. Animal 8:534-541.

VDLUFA. 1976. Verband Deutscher Landwirtschaftlicher Untersuchungs- und Forschungsanstalten. Handbuch der landwirtschaftlichen Versuchs- und Untersuchungsmethodik (VDLUFA-Methodenbuch), Vol. III. Die chemische Untersuchung von Futtermitteln mit 1.-8. Ergänzungslieferung (1983-2012), 3rd ed. VDLUFA-Verlag, Darmstadt, Germany.

Wolfinger, R. D. 1996. Heterogeneous variance-covariance structures for repeated measures. J. Agric. Biol. Environ. Sci. 1:205-230.

Yanke, L. J., H. D. Bae, L. B. Selinger, and K.-J. Cheng. 1998. Phytase activity of anaerobic ruminal bacteria. Microbiology 144:1565-1573.

Yiu, S. H., I. Altosaar, and R. G. Fulcher. 1983. The effects of commercial processing on the structure and microchemical organization of rapeseed. Food Microstruct. 2:165-173.

Zeller, E., M. Schollenberger, I. Kühn, and M. Rodehutscord. 2015. Hydrolysis of phytate and formation of inositol phosphate isomers without or with supplemented phytases in different segments of the digestive tract of broilers. J. Nutr. Sci. 4:e1. https://doi. org/10.1017/jns.2014.62. 